\title{
MicroRNA-200a mediates nasopharyngeal carcinoma cell proliferation through the activation of nuclear factor- $\mathrm{\kappa B}$
}

\author{
ZHULIANG SHI $^{1 *}$, ZHIQIANG HU ${ }^{1 *}$, DELU CHEN $^{1}$, JIE HUANG $^{1}$, JIE FAN $^{1}$, \\ SUBO ZHOU ${ }^{1}$, XIN WANG $^{1}$, JIANDAO HU ${ }^{2}$ and FEI HUANG ${ }^{3}$ \\ ${ }^{1}$ Department of Ear, Nose and Throat, People's Liberation Army 113th Hospital, Ningbo, Zhejiang 315000; \\ ${ }^{2}$ Department of Ear, Nose and Throat, Yinzhou Hospital Affiliated to The Medical School of Ningbo University, \\ Ningbo, Zhejiang 315000; ${ }^{3}$ Department of Stomatology, People's Liberation Army Navy General Hospital, \\ Beijing 100048, P.R. China
}

Received June 10, 2014; Accepted August 7, 2015

DOI: $10.3892 / \mathrm{mmr} .2015 .4738$

\begin{abstract}
In nasopharyngeal carcinoma (NPC), the nuclear factor- $\kappa \mathrm{B}(\mathrm{NF}-\kappa \mathrm{B})$ signaling pathway is highly active. The constitutive activation of $\mathrm{NF}-\kappa \mathrm{B}$ prompts malignant cell proliferation, and microRNAs are considered an important mediator in regulating the $\mathrm{NF}-\kappa \mathrm{B}$ signaling pathway. The current study investigated the effect of microRNA-200a (miR-200a) on $\mathrm{NF}-\kappa \mathrm{B}$ activation. Reverse transcription-quantitative polymerase chain reaction was used to quantify the relative level of miR-200a in NPC tissue samples and CNE2 cells. An MTT assay was used to investigate the effect of miR-200a on cell proliferation. To investigate the activation of $\mathrm{NF}-\kappa \mathrm{B}$, western blotting was used to measure the protein levels of $\mathrm{NF}-\kappa \mathrm{B}$ and its downstream targets. To identify the target genes of miR-200a, a luciferase reporter assay was used. The current study demonstrated that miR-200a was upregulated in NPC tissue samples and cell lines. Overexpression of miR-200a resulted in the proliferation of CNE2 cells. Western blot analysis indicated that the protein levels of p65 increased when CNE2 cells were transfected with miR-200a mimics. Additionally, the downstream targets of miR-200a were upregulated, including vascular cell adhesion molecule, intercellular adhesion molecule and monocyte chemoattractant protein-1. The luciferase assay indicated that $\mathrm{I} \kappa \mathrm{B} \alpha$ was the target gene of miR-200a. In
\end{abstract}

Correspondence to: Dr Jiandao Hu, Department of Ear, Nose and Throat, Yinzhou Hospital Affiliated to The Medical School of Ningbo University, 177 West Road, Taian, Ningbo, Zhejiang 315000, P.R. China

E-mail: hujiandao@163.com

Dr Fei Huang, Department of Stomatology, People's Liberation Army Navy General Hospital, 6 Fucheng Road, Haidian District, Beijing 100048, P.R. China

E-mail: 147148419@163.com

*Contributed equally

Key words: miR-200a, nasopharyngeal carcinoma cell, NF-кB activation conclusion, miR-200a was demonstrated to enhance NPC cell proliferation by activating the $\mathrm{NF}-\kappa \mathrm{B}$ signaling pathway.

\section{Introduction}

As a squamous cell carcinoma, nasopharyngeal carcinoma (NPC) is derived from the epithelium of the nasopharynx. Compared with the rest of the world, the incidence of NPC in China is high (1), and therefore is a serious public health problem in China. In regions covered by the cancer registries in 2009, the crude incidence of NPC was 3.61/100,000 (5.08/100,000 in males and 2.10/100,000 in females; 4.19/100,000 in urban areas and 2.42/100,000 in rural areas) (1). Due to the high incidence of early metastasis, the rate of mortality is high in patients with NPC. At present, radiotherapy is the first choice of therapy for patients with NPC. However, despite improvements in the standards of radiotherapy, the five-year survival rate remains to be $\sim 50-60 \%$ (2). Therefore, it is important for clinicians and researchers to develop novel effective treatment strategies.

The transcription factor nuclear factor- $\kappa \mathrm{B}(\mathrm{NF}-\kappa \mathrm{B})$ consists of 5 subunits; Rel (cRel), p65 (RelA, NF-кB3), RelB, p50

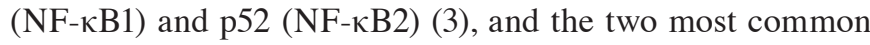
dimers of NF- $\kappa \mathrm{B}$ are p65 and p50 (3). In unstimulated cells, inhibitory $\kappa \mathrm{B}(\mathrm{I} \kappa \mathrm{B})$ is bound to $\mathrm{NF}-\kappa \mathrm{B}$, which remains in an inactive form in the cytoplasm (3). When cells are stimulated by extracellular signals, IкB kinase complex (IKK) phosphorylates I $\mathrm{B}$, exposing the nuclear localization sites of $\mathrm{NF}-\kappa \mathrm{B}(3)$. Subsequently the free $\mathrm{NF}-\kappa \mathrm{B}$ translocates into the nucleus where it binds with specific $\kappa \mathrm{B}$ sequences, inducing gene transcription (3). Previous histological studies have indicated the importance of local inflammation in NPC tumorigenesis (4). As a key inflammatory signaling pathway, $\mathrm{NF}-\kappa \mathrm{B}$ has been demonstrated to be constitutively active in NPC tissue by immunohistochemical staining (4). The constitutive activation of NF- $\kappa \mathrm{B}$ commonly results in malignant carcinoma cell proliferation in various types of cancer cells and tissues, as the $\mathrm{NF}-\kappa \mathrm{B}$ signaling pathway regulates a series of target genes involved in cell proliferation, apoptosis, immune responses and transcription (5).

MicroRNAs (miRNAs) are small non-coding RNAs of 20-25 nucleotides. miRNAs negatively regulate gene 
expression by recognizing complementary sequences in the 3'-untranslated regions (UTR) of target mRNAs, resulting in their degradation (6). In previous studies, the aberrant expression of miRNAs has been associated with various types of human cancer $(7,8)$. In addition, as an important mediator, miRNAs are accepted as key modulators and effectors of the NF- $\mathrm{B}$ signaling pathway. For example, miR-146a and miR-146b negatively interact with interleukin-1 receptor-associated kinase 1 and tissue necrosis factor receptor-associated factor 6 protein levels, resulting in the activation of $\mathrm{NF}-\kappa \mathrm{B}(9)$. Furthermore, miR-199a has been demonstrated to suppress IKK $\beta$, which reduces the activity of $N F-\kappa B$ signaling (10), whilst miR-200a has been reported to regulate various signaling pathways through targeting different genes, including epidermal growth factor receptor, c-Met and ephrin type-A receptor $1(11,12)$.

In the current study, the relative expression levels of miR-200a were investigated in human NPC. In addition, the impact of increased miR-200a levels on NPC cell proliferation and migration was explored. The present study aimed to elucidate the effect of miR-200a on NPC cell proliferation and the role of the $\mathrm{NF}-\kappa \mathrm{B}$ signaling pathway in this process.

\section{Materials and methods}

Human samples and cell lines. A total of 40 samples of primary human NPC and 30 normal samples were collected at the People's Liberation Army 113th hospital (Ningbo, China) and written informed consent was obtained from all patients. Clinical information was obtained by reviewing the medical records on radiographic images, by telephone or written correspondence, and by reviewing death certificates. All specimens had confirmed pathological diagnosis and were staged according to the 1992 NPC staging system of China (13). The NPC cell lines (HNE1, CNE1 and CNE2) and an immortalized nasopharyngeal epithelial cell line (NP69) were purchased from the American Type Culture Collection (Manassas, VA, USA) and cultured in Eagle's minimum essential medium (MEM; GE Healthcare Life Sciences, Logan, UT, USA) with $10 \%$ fetal bovine serum(FBS; GE Healthcare Life Sciences). The HEK293T cells were cultured in $2 \mathrm{ml}$ Dulbecco's modified Eagle's medium (GE Healthcare Life Sciences) supplemented with $100 \mathrm{U} / \mathrm{ml}$ penicillin (Beijing SolarBio Science \& Technology Co., Ltd., Beijing, China, Beijing, China), $100 \mathrm{U} / \mathrm{ml}$ streptomycin and 10\% FBS.

Tumor necrosis factor- $\alpha(T N F-\alpha)$ treatment. CNE2 cells were seeded in the six-well plate at the concentration of $1 \times 10^{6}$ cells/well. After $24 \mathrm{~h}$, the CNE2 cells were treated with $10 \mathrm{ng} / \mathrm{ml} \mathrm{TNF} \alpha$ for $48 \mathrm{~h}$. The relative levels of miR-200a were then determined.

Transient transfection procedures. Shortly prior to transfection, $1.5 \times 10^{5}$ cells were seeded per well in a 6 -well plate in $2 \mathrm{ml}$ Dulbecco's modified Eagle's medium containing serum and supplemented with $100 \mathrm{U} / \mathrm{ml}$ penicillin and $100 \mathrm{U} / \mathrm{ml}$ streptomycin. Prior to transfection, the cells were incubated under normal growth conditions (typically $37^{\circ} \mathrm{C}$ and $5 \% \mathrm{CO}_{2}$ ). Subsequently, miR-200a mimics, miR-200a inhibitor or the miR negative control (Shanghai Genepharma Co., Ltd.,
Shanghai, China) were pre-incubated with HiPerFect transfection reagent (Qiagen China Co., Ltd., Shanghai, China) with the final concentration of microRNA analogues at $100 \mathrm{nmol} / \mathrm{l}$. The sequence of miR-200a was as follows: 5'-CAGUGCAAU AGUAUUGUCAAAGC-3'.

siRNA transfection. Specific siRNA targeting p65 was purchased from Shanghai Jima Co. (Shanghai, China). The siRNAs were transfected into the cells using Vigofect transfection reagent (Vigorous Biotechnology Beijing Co., Ltd., Beijing, China).

RNA extraction. Total RNA ( $2 \mu \mathrm{g})$ was extracted from cell lines and human samples $(5 \mathrm{mg})$ with TRIzol reagent (Invitrogen Life Technologies, Carlsbad, CA, USA) according to the manufacturer's instructions.

Reverse transcription-quantitative polymerase chain reaction $(R T-q P C R)$. In order to detect and quantify mature miRNA-200a, a TaqMan MicroRNA Reverse Transcription kit and a TaqMan MicroRNA Assay were used according to the manufacturer's instructions (Applied Biosystems Life Technologies, Foster City, CA, USA). U6 RNA was used for normalization. To quantify miRNA levels, $10 \mathrm{ng}$ total RNA was reverse transcribed using TaqMan MicroRNA Reverse Transcription kit (Applied Biosystems Life Technologies) with specific primers for miR-200a and U6. Subsequently, the PCR amplifications were performed in $20 \mu \mathrm{l}$ reaction volume containing $10 \mu \mathrm{g}$ TaqMan 2X Universal PCR Master Mix, $1 \mu 1$ 20X TaqMan MicroRNA Assay mix (Applied Biosystems Life Technologies) and $1.33 \mu$ l template cDNA in the same system used for mRNA quantification. The thermal cycling conditions were as follows: $95^{\circ} \mathrm{C}$ for $10 \mathrm{~min}$, followed by 40 cycles at $95^{\circ} \mathrm{C}$ for $15 \mathrm{sec}$ and $60^{\circ} \mathrm{C}$ for $1 \mathrm{~min}$. Relative miRNA expression of miR-200a was normalized against the endogenous control, U6 RNA, using the comparative $2^{-\Delta \Delta \mathrm{Ct}}$ method (14). CFX Manager $^{\text {TM }}$ software (Bio-Rad Laboratories, Inc., Hercules, CA, USA) was used for quantification analysis for mRNA and miRNA. For reverse transcription, the specific primers are listed, as follows: (5'-3'): miR-200a, CUGGAUUUCCCA GCUUGACUCUAACACUGUCUGGUAACGAUGUUCAAA GGUGACCCGC; U6, GTCGTATCCAGTGCAGGGTCC GAGGTATTCGCACTGGATACGACAAATATG. The primers used for qPCR were as follows (5'-3'): miR-200a forward, GCAAAGTGCATCCATTTTGTTTGT; U6 forward, GCGCGTCGTGAAGCGTTC; universal reverse primer, GTGCAGGGTCCGAGGT.

Protein extraction, western blotting and antibodies. Cellular proteins were extracted using RIPA buffer $[50 \mathrm{mM}$ Tris/ $\mathrm{HCl}$, pH 7.4, $150 \mathrm{mM} \mathrm{NaCl,} \mathrm{1 \%} \mathrm{(v/v)} \mathrm{NP-40,} \mathrm{0.1 \%} \mathrm{(w/v)} \mathrm{SDS;}$ Beijing SolarBio Science \& Technology Co., Ltd.) containing $1 \%$ (v/v) phenylmethanesulfonylfluoride (Beijing SolarBio Science \& Technology Co., Ltd.), $0.3 \%$ (v/v) protease inhibitor (Sigma-Aldrich, St. Louis, MO, USA) and 0.1\% (v/v) phosphorylated proteinase inhibitor (Sigma-Aldrich). Lysates were centrifuged at $13,000 \mathrm{~g}$ at $4^{\circ} \mathrm{C}$ for $15 \mathrm{~min}$ and the supernatant was collected for total protein analysis. A bicinchoninic acid protein assay kit (Pierce Biotechnology, Inc., Rockford, IL, USA) was used to determine the protein concentration. Equal 
amounts of protein $(15 \mu \mathrm{g})$ were separated on an SDS-PAGE gel $[10 \%$ (v/v) polyacrylamide; Beijing SolarBio Science \& Technology Co., Ltd.] and transferred onto a polyvinylidene fluoride membrane (Merck Millipore, Darmstadt, Germany). Nonspecific binding was blocked using $8 \%(\mathrm{w} / \mathrm{v})$ milk in Tris-buffered saline-Tween 20 (TBST) for $2 \mathrm{~h}$ at room temperature. The membranes were incubated with primary antibodies against $\beta$-actin (8H10D10; mouse monoclonal; cat. no. 3700; 1:3,000, Cell Signaling Technology, Inc., Danvers, MA, USA), NF-kB p65 (D14E12) XP ${ }^{\circledR}$ Rabbit mAb (cat. no. 8242; 1:1,000; Cell Signaling Technology, Inc.), NF-кB1 p105/p50 antibody (cat. no. 3035; 1:1,000; Cell Signaling Technology, Inc.), Cox2 (D5H5) XP® rabbit mAb (cat. no. 12282; 1:1,000; Cell Signaling Technology, Inc.), MMP-2 (D8N9Y) rabbit mAb (cat. no. 13132; 1:1,000; Cell Signaling Technology, Inc.), human vascular endothelial growth factor-165 (cat. no. 8065; 1:1,000; Cell Signaling Technology, Inc.) Phosphorylated (p)-NF-кB p65 (Ser536; 93H1) rabbit mAb (cat. no. 3033; 1:1,000; Cell Signaling Technology, Inc.), ICAM-2 (D7P2Q) rabbit mAb (cat. no. 13355; 1:1,000, Cell Signaling Technology, Inc.), MCP-1 antibody (cat. no. 2027; 1:1,000; Cell Signaling Technology, Inc.) and IкB $\alpha$ (44D4) rabbit $\mathrm{mAb}$ (cat. no. 4812; 1:1,000; Cell Signaling Technology, Inc.) overnight at $4^{\circ} \mathrm{C}$. Following three washes with TBST, the membranes were incubated in horseradish peroxidase (HRP)-conjugated goat anti-rabbit (cat. no. ZB-2307; 1:5,000; Zhongshan Gold Bridge Biotechnology Co., Ltd., Beijing, China) and anti-mouse (cat. no. ZB-2305 1:5,000; Zhongshan Gold Bridge Biotechnology, Co., Ltd.) or HRP-conjugated mouse anti-goat antibodies (cat. no. ZB-5305; Beijing Zhongshan Jinqiao Biotechnology Co., Ltd., Beijing, China; 1:5,000) for $2 \mathrm{~h}$ at room temperature and then washed with TBST three times (5 min each). The target proteins were subsequently visualized using enhanced chemiluminescence (EMD Millipore, Billerica, MA, USA) according to the manufacturer's instructions and quantified using density analysis with ImageJ 4.0 software (National Institutes of Health, Bethesda, MA, USA) normalized against $\beta$-actin, and expressed as the fold-change, compared with the control.

Luciferase target assay. TargetScan (http://www.targetscan. org/) was used to determine the potential binding sites of miR-200a on the 3'UTR of I $\mathrm{B} B \alpha$. For the luciferase assay, the $3^{\prime} \mathrm{UTR}$ of $\mathrm{I} \kappa \mathrm{B} \alpha$, including the binding site for miR-200a, was amplified from $\mathrm{CNE} 2$ cells using the following primers: IкB $\alpha$-F, 5'-AAGGAGGAGGGCAGA ATCAT-3'; IкB $\alpha$-R, 5'-ATCTGCATGGTGATGTTGGA-3'.

The PCR product was digested with $X b a \mathrm{I}$ (New England Biolabs, Beverly, MA, USA) and cloned into the reporter plasmid pGL3 (Promega Corporation, Madison, WI, USA) downstream of the luciferase reporter gene. The modified firefly luciferase vector (500 ng/ $/ \mu \mathrm{l}$; Promega Corporation) was transfected into HEK 293 cells ( $2 \times 10^{5}$ cells $/ \mathrm{ml}$; as previously described). Firefly and Renilla luciferase activities were measured $48 \mathrm{~h}$ following transfection with the Dual-Luciferase Reporter Assay System (Promega Corporation). Firefly activity was normalized to Renilla activity to control the transfection efficiency.

Dihydroethidium (DHE) staining. The cells were cultured in six-well chamber slides at a density of $1 \times 10^{6}$ cells/well, washed with PBS three times (5 min/wash) and incubated with ROS Fluorescent Probe-DHE (10 $\mu \mathrm{M}$; Vigorous Biotechnology Beijing Co., Ltd.) in serum-free DMEM F-12 medium for $30 \mathrm{~min}$ at $37^{\circ} \mathrm{C}$ in the dark. Following incubation, the slides were fixed in $4 \%$ paraformaldehyde for $30 \mathrm{~min}$ at room temperature, were washed again and mounted. Immunofluorescence images were captured using fluorescence microscopy (Leica CM3000; Leica Microsystems GmbH, Wetzlar, Germany).

Dimethyl thiazolyl diphenyl tetrazolium (MTT) assay. To evaluate the effect of miR-200a on cell proliferation, cells were seeded 5,000 cells/well in $100 \mu 1 \mathrm{MEM}$ in 96-well plates and transfected with miR-200a mimics $(50 \mathrm{nM})$ and negative control-miRNA mimics $(50 \mathrm{nM})$, as described above. At 24 , 48 and $72 \mathrm{~h}$ post-transfection, $20 \mu \mathrm{l}$ MTT reagent (Beijing SolarBio Science \& Technology Co., Ltd.) was added to the wells, which were then incubated for $4 \mathrm{~h}$ at $37^{\circ} \mathrm{C}$. Following removal of the medium, $200 \mu \mathrm{l}$ dimethyl sulfoxide was added to dissolve the formazan and the absorbance was measured at $550 \mathrm{~nm}$. Wells containing only CNE2 cells, which served as blanks.

Statistical analysis. Data are presented as the mean \pm standard error from 3 independent experiments. Statistical analysis was conducted with Student's t-test using GraphPad Prism 5 software (National Institutes of Health). $\mathrm{P}<0.05$ was considered to indicate a statistically significant difference.

\section{Results}

miR-200a is upregulated in human NPC cells and tissue samples. The relative levels of miR-200a in human NPC cells and tissue samples were measured in human NPC cells and patient tissue samples using RT-qPCR. Compared with NP69 immortalized nasopharyngeal epithelial cells, miR-200a levels were increased by greater than 2.38-fold in HNE1, CNE1 and CNE2 human NPC cells, and miR-200a expression levels were normalized to U6 $(\mathrm{P}<0.05$; Fig. 1A). The expression levels of miR-200a were measured in 40 human NPC cancer specimens compared with 30 normal tissue samples. Compared with the normal tissue, the mean expression level of miR-200a was increased by greater than 3 -fold $(\mathrm{P}<0.05$; Fig. 1B). This indicated that miR-200a was significantly increased in the human NPC cells and tumor tissue.

Downregulation of miR-200a increases CNE2 cell viability. In order to investigate the effect of miR-200a on CNE2 cell viability, CNE2 cells were transfected with miR-200a mimics, miR-200a inhibitors or the negative control for 24 , 48 and $72 \mathrm{~h}$. In the current study, the mimics were analogues that enhanced miR-200a expression levels while inhibitors were analogues that reduced the expression of miR-200a. The MTT assay indicated that when miR-200a mimics were transfected into CNE2 human NPC cells, cell viability was significantly decreased by 23 and $35 \%$ at 48 and $72 \mathrm{~h}$, respectively (Fig. 2A). However, when miR-200a expression was inhibited, cell viability was enhanced by 17 and $36 \%$ at 48 and $72 \mathrm{~h}$, respectively (Fig. 2B). These results indicated that miR-200a may increase CNE2 cell viability. 
A

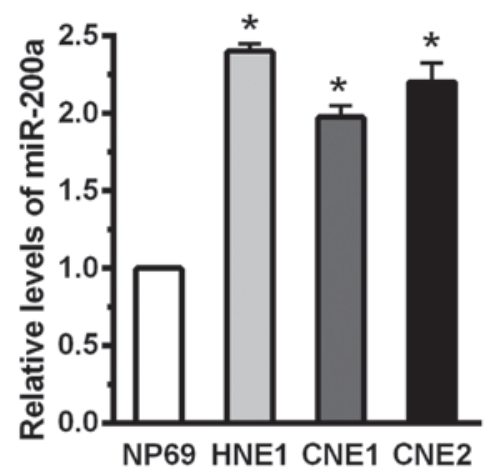

B

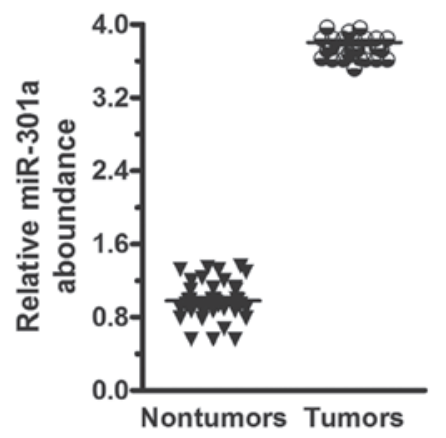

Figure 1. Expression levels of miR-200a in human NPC cells and tissue samples. (A) Reverse transcription-quantitative polymerase chain reaction analysis of miR-200a expression in HNE1, CNE1 and CNE2 human NPC cells and NP69 immortalized nasopharyngeal epithelial cells. (B) Analysis of miR-200a expression in 40 human NPC tissue samples (Tumors) and paired nontumor tissue samples (Nontumors). U6 was used as an endogenous control. "P<0.05, vs. NP69. miR-200a, microRNA-200a, NPC, nasopharyngeal carcinoma.

A

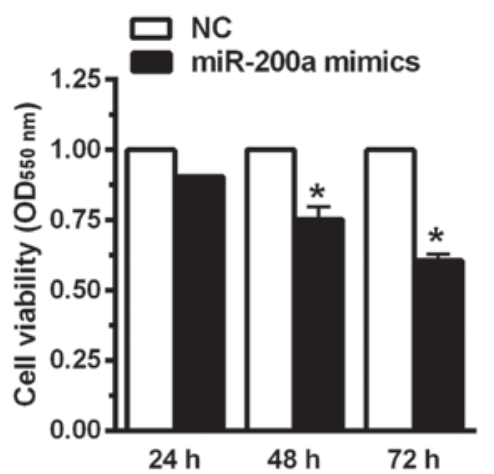

B

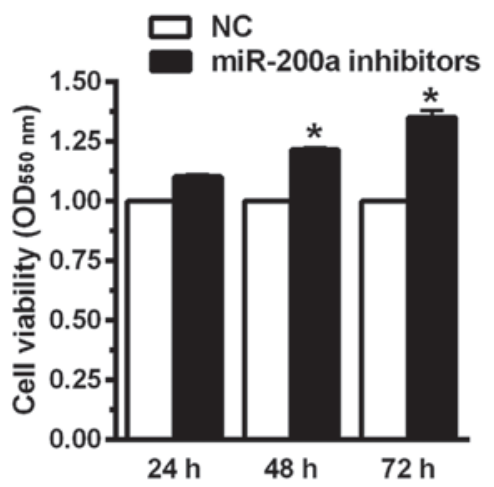

Figure 2. CNE2 human NPC cell viability was altered by miR-200a. CNE2 cells were transfected with (A) miR-200a mimics, (B) miR-200a inhibitors or the negative control for 24,48 and $72 \mathrm{~h}$. Cell viability was measured using an MTT assay. Data represent the mean \pm standard error, $\mathrm{n}=6$ independent experiments. ${ }^{*} \mathrm{P}<0.05$ vs. NC. NPC, nasopharyngeal carcinoma; miR-200a, microRNA-200a; NC, negative control; OD, optical density.
miR-200a activates the $N F-\kappa B$ signaling pathway. In NPC, the NF- $\mathrm{kB}$ signaling pathway is constitutively activated (15). In the current study, CNE2 cells were treated with $10 \mathrm{ng} / \mu \mathrm{l}$ TNF- $\alpha$ for $48 \mathrm{~h}$, following which the relative levels of miR-200a were measured. As presented in Fig. 3A, the relative level of miR-200a was increased by greater than 4.8 -fold with TNF- $\alpha$ treatment. To address whether miR-200a contributes to NF- $\kappa B$ activation, CNE2 cells were transfected with miR-200a mimics. Western blot analysis indicated that when miR-200a was overexpressed, NF- $\mathrm{KB}$ was significantly activated. As presented in Fig. 3, compared with the negative control, the $\mathrm{p}-\mathrm{NF}-\kappa \mathrm{B} / \mathrm{NF}-\mathrm{\kappa B}$ ratio was increased by greater than 2.36-fold (Fig. 3B). Vascular cell adhesion molecule (VCAM), intercellular adhesion molecule (ICAM) and monocyte chemoattractant protein-1 (MCP-1) are important adhesion molecules that are aberrantly increased in various types of cancer (16). To further investigate the alterations in NF- $\kappa \mathrm{B}$ activation, the protein levels of VCAM, ICAM and MCP-1 were measured. As presented in Fig. 3B, the relative levels of VCAM, ICAM and MCP-1 were significantly increased. Together, these data indicate that miR-200a contributed to TNF- $\alpha$-stimulated $\mathrm{NF}-\kappa \mathrm{B}$ activation. To investigate the effect of NF- $\kappa \mathrm{B}$ on cell proliferation, a small interfering RNA (siRNA) targeting $\mathrm{NF}-\mathrm{\kappa B}$ was used. Following treatment with the siRNA against $\mathrm{NF}-\kappa \mathrm{B}$, the protein levels of NF- $\mathrm{KB}$ were reduced, as were the expression levels of VCAM, ICAM and MCP-1. Additionally, this effect was observed in the cells transfected with miR-200a mimics (Fig. 3C). VCAM was increased by 2.1-fold following the addition of mimics, although the reduction in MCP-1 was less marked. Furthermore, as presented in Fig. 3D, with NF- $\kappa B$ knockdown, cell viability was significantly reduced even in the cells transfected with miR-200a mimics. These data suggest that miR-200a enhances cell proliferation through the activation of the NF- $\mathrm{kB}$ signaling pathway.

$I \kappa B \alpha$ is the host gene of miR-200a. To further investigate whether NF- $\mathrm{KB}$ was activated by miR-200a overexpression, immunofluorescence was used. As presented inFig. 4A, increased NF- $\kappa$ B (p65) protein levels were observed when CNE2 cells were transfected with miR-200a mimics. In previous studies, numerous miRNAs have been reported to activate NF- $\mathrm{kB}$, for instance, miR-200a targeted NF-кB-repressing factor and correlated with altered NF- $\kappa B$ activation $(17,18)$. In the current study, the target gene of miR-200a was identified using a bio-informatics database. TargetScan predicted miR-200a to target position 356-362 in the

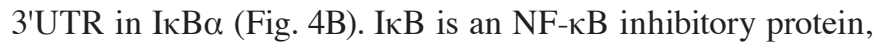
which in unstimulated cells is bound to p65 and P50, resulting in the inactivation of NF- $\mathrm{\kappa B}$ in the cytoplasm (19). Following the activation of IKK, I $\mathrm{KB} \alpha$ is degraded and the two subunits of $\mathrm{NF}-\mathrm{\kappa B}$ translocate from the cytoplasm to the nucleus, thereby inducing the downstream signaling pathway (20). Therefore, the effect of miR-200a on IкB $\alpha$ expression was investigated. When CNE2 cells were transfected with miR-200a mimics for $4 \mathrm{~h}$, the expression levels of $\mathrm{I} \kappa \mathrm{B} \alpha$ were significantly reduced compared with the negative control (Fig. 4B). Furthermore, $48 \mathrm{~h}$ following transfection with miR-200a in CNE2 cells, the expression level of I $\mathrm{B} \alpha$ was reduced by $56 \%$. However, when miR-200a was inhibited in CNE2 cells, the expression level of $\mathrm{I} \kappa \mathrm{B} \alpha$ was increased by almost 1-fold (Fig. 4C). A luciferase reporter assay was used to investigate the effect of miR-200a on the 3'-UTR 
A

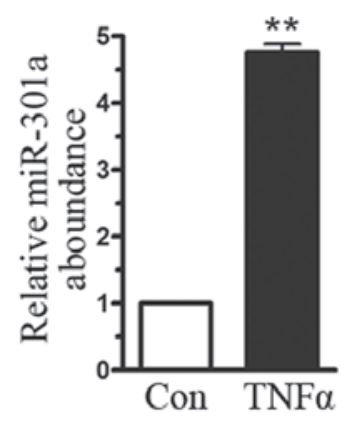

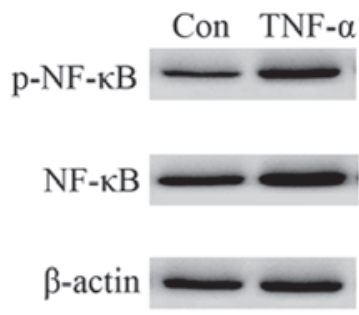

B

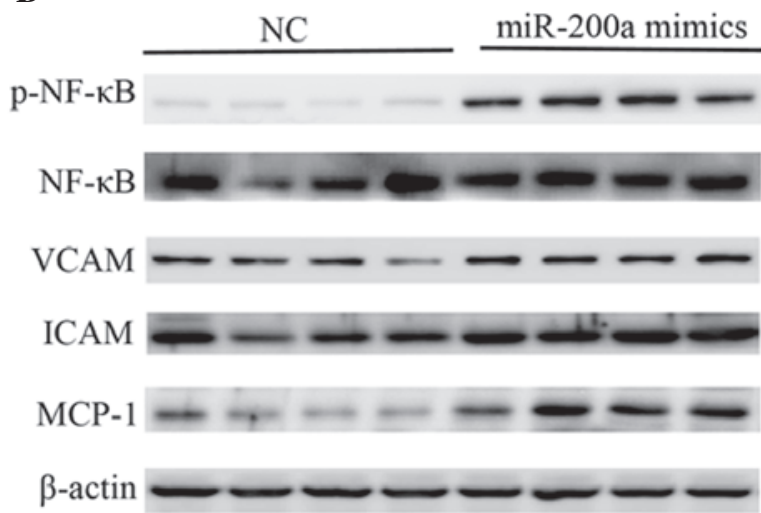

C

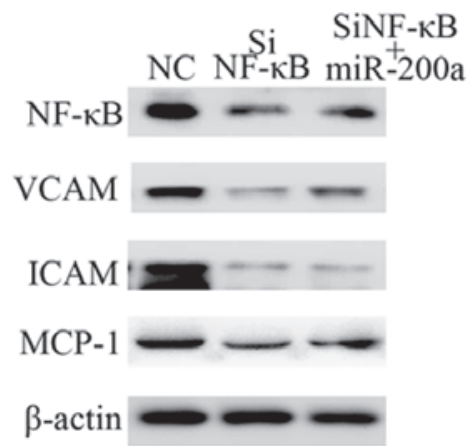

D
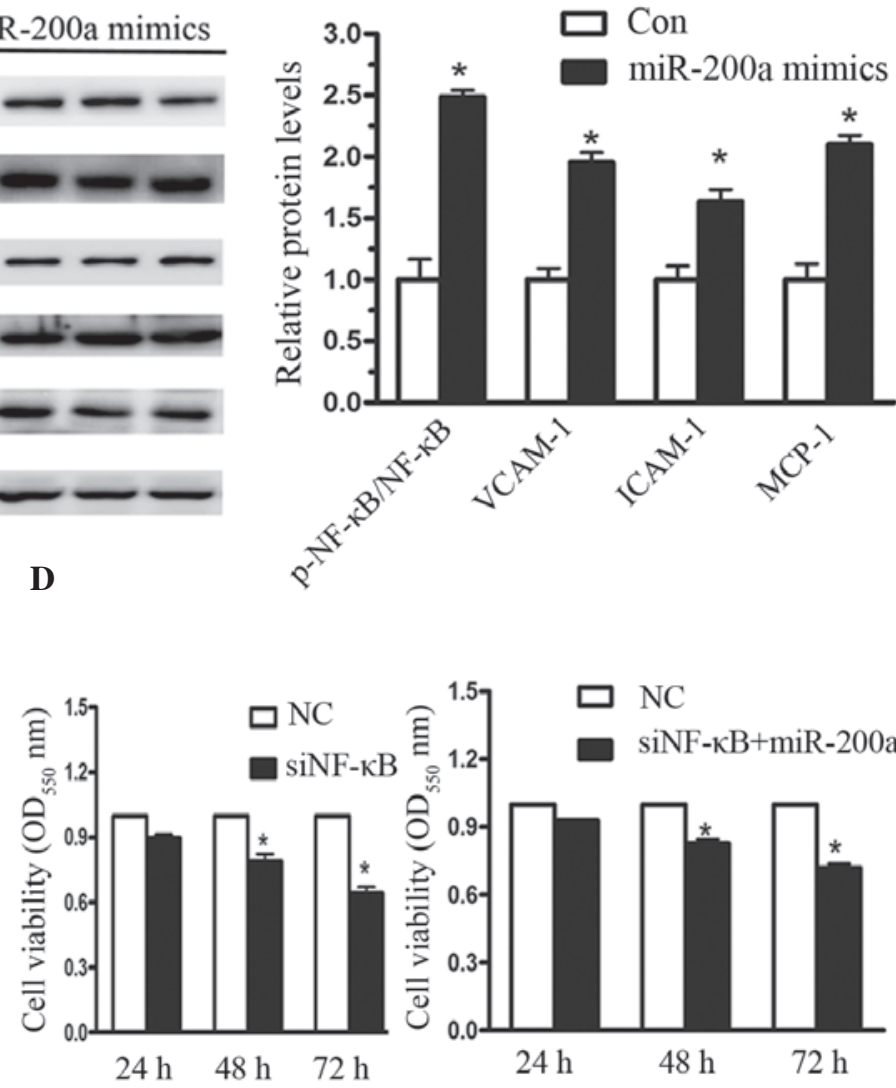

Figure 3. NF- $\mathrm{B}$ B signaling pathway activation with overexpression of miR-200a in CNE2 cells. (A) Reverse transcription-quantitative polymerase chain reaction was used to measure the relative levels of miR-200a when CNE2 cells were treated with $10 \mathrm{ng} / \mu 1 \mathrm{TNF} \alpha$ for $48 \mathrm{~h}$. (B) Western blot analysis of $\mathrm{NF}-\kappa \mathrm{B}$ activation and its downstream regulators following miR-200a overexpression. (C) Western blot analysis of an short interfering RNA targeting NF- $\kappa \mathrm{B}$. (D) MTT assay indicated a reduced rate of cell proliferation in cells cotransfected with si-NF- $\kappa \mathrm{B}$ and miR-200a mimics. Data represent the mean \pm standard error, $n=3$ independent experiments. ${ }^{*} \mathrm{P}<0.05$ vs. control. $\mathrm{NF}-\kappa \mathrm{B}$, nuclear factor- $\kappa \mathrm{B}$; miR-200a, microRNA-200a; TNF $\alpha$, tissue necrosis factor $\alpha$; si-NF- $\kappa \mathrm{B}$,

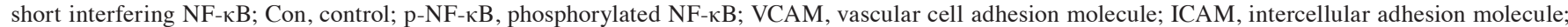
MCP-1, monocyte chemoattractant protein-1.

of $\mathrm{I} \kappa \mathrm{B} \alpha$, and indicated that miR-200a significantly reduced IкB $\alpha-3$ '-UTR-luciferase reporter activity (Fig. 4D). These data indicated that miR-200a induced NF- $\mathrm{KB}$ activation, predominantly by targeting $\mathrm{I} \kappa \mathrm{B} \alpha$ in the human NPC cells.

\section{Discussion}

MicroRNAs have been widely demonstrated to regulate various cellular processes, in particular cancer development and progression (21). NPC is common in men and women and several studies have indicated abnormal miRNA levels in NPC $(22,23)$. The current study reported that miR-200a was upregulated in CNE2 human NPC cells and suggests an oncogenic role for miR-200a in NPC progression.
In order to investigate the association between miR-200a and human NPC, the relative levels of miR-200a were measured in human NPC cells and tissue samples. This indicated that miR-200a was upregulated in human NPC. Furthermore, the MTT assay demonstrated that miR-200a is able to activate CNE2 cell proliferation. TNF- $\alpha$ treatment was observed to induce increased expression of miR-200a, with a 4-fold increase in CNE2 cells. In addition, $N F-\kappa B$ was activated when CNE2 cells were transfected with miR-200a mimics for $48 \mathrm{~h}$, and upregulation of the downstream regulators of $\mathrm{NF}-\kappa \mathrm{B}$ signaling was observed, including that of VCAM, ICAM and MCP-1. The activation of the NF- $\kappa$ B signaling pathway was further validated via the investigation of the relative levels of $\mathrm{I} \kappa \mathrm{B} \alpha$ using western blotting and a luciferase reporter assay. 
A

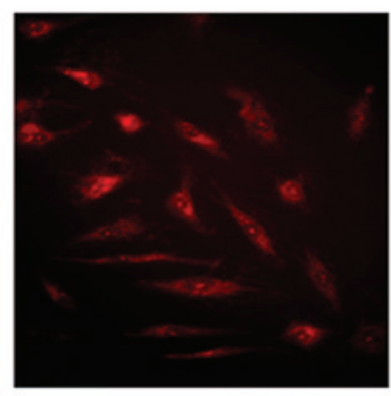

Con

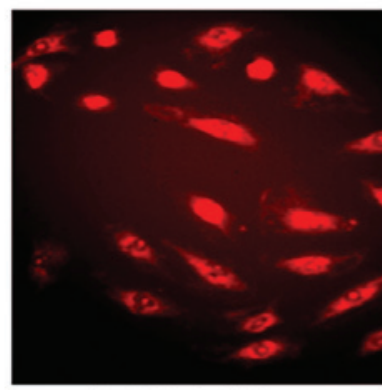

miR-200a inhibitors
B

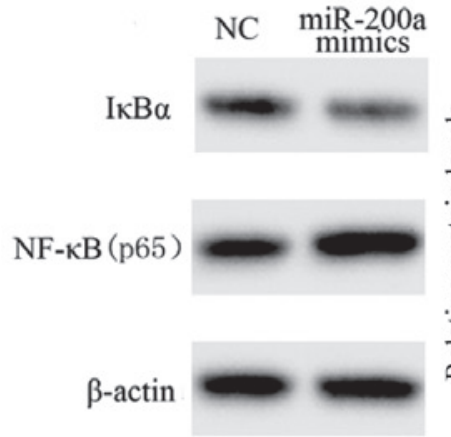

D

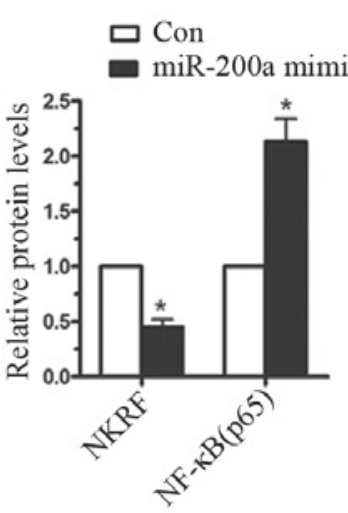

C
NC $\underset{\substack{m i R \\ \text { inhibitors }}}{\underset{2}{2} 20 \mathrm{a}}$
口 Con
miR-200a inhibitors

I $\alpha$
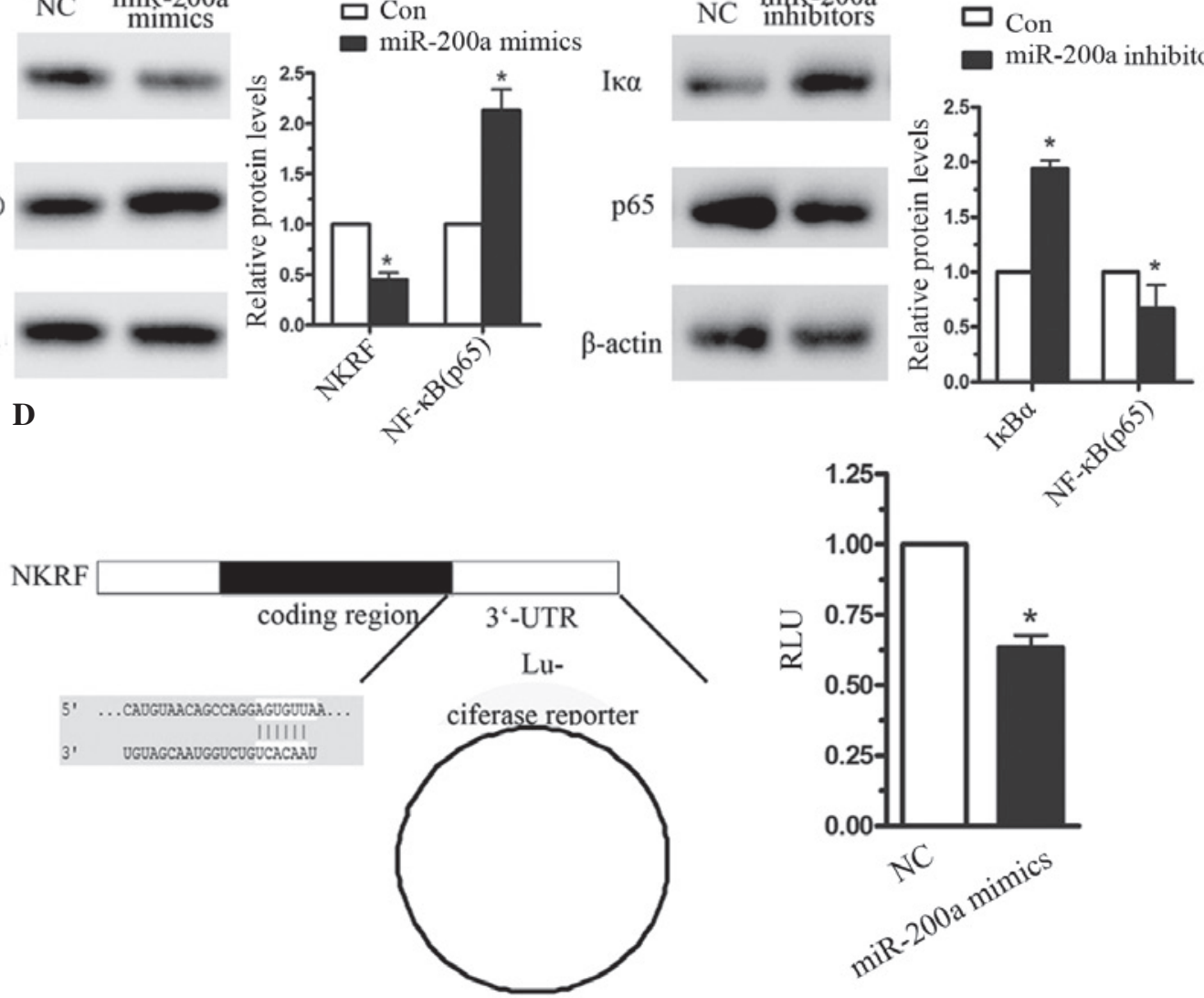

Figure 4. miR-200a targets I $\mathrm{B} \alpha$ in CNE2 cells. (A) Immunofluorescence analysis of NF- $\kappa B$ expression in CNE2 cells following transfection with miR-200a inhibitors or the negative control. (B) Western blot analysis of IкB $\alpha$, following transfection of CNE2 cells with (B) miR-200a mimics, (C) miR-200a inhibitors and the negative control. (D) A luciferase reporter assay was used to investigate the effect of miR-200a on IкB $\alpha-3^{\prime}-U T R$. Data are presented as the mean \pm standard error, $n=3$ independent experiments. " $\mathrm{P}<0.05$ vs. control. miR-200a, microRNA-200a; IкB, inhibitory $\kappa B$; NF- $\kappa B$, nuclear factor- $\kappa B$; UTR, untranslated region; NC, negative control, NKRF, NF- $\kappa \mathrm{B}$ repressing factor.

Together, these data indicated that miR-200a induced NF- $\kappa \mathrm{B}$ activation through the targeting $\mathrm{I} \kappa \mathrm{B} \alpha$.

Dysregulation of the $\mathrm{NF}-\kappa \mathrm{B}$ signaling pathway is well characterized in cancer cell proliferation, angiogenesis, migration and invasion $(24,25)$; NF- $\kappa \mathrm{B}$ signaling has been observed to be significantly activated in glioma, and the $\mathrm{NF}-\kappa \mathrm{B}$ pathway has been reported to significantly induce cancer cell proliferation and invasion in thyroid cancer. The current study provided further evidence of $\mathrm{NF}-\kappa \mathrm{B}$ activation in human NPC and investigated the association with miR-200a. These data indicated that $\mathrm{NF}-\kappa \mathrm{B}$ and its downstream regulator proteins were positively regulated by miR-200a. In addition, the current study demonstrated that $\mathrm{I} \kappa \mathrm{B} \alpha$ is a target gene for miR-200a. I $\mathrm{B} \alpha$ has been demonstrated to repress $\mathrm{NF}-\kappa \mathrm{B}$ translation through binding with specific negative regulatory elements (26).

In conclusion, increased levels of miR-200a were observed in the current study in human NPC tissue samples and cell lines. In addition, miR-200a was demonstrated to enhance the proliferation of CNE2 cells. Furthermore, miR-200a activated the $\mathrm{NF}-\kappa \mathrm{B}$ signaling pathway through targeting $\mathrm{I} \kappa \mathrm{B} \alpha$, a negative regulator of $\mathrm{NF}-\kappa \mathrm{B}$.

\section{Acknowledgements}

This study was supported by grants from the National Natural Science Foundation of Ningbo (grant nos. 2013A610215 and 2014A610230). 


\section{References}

1. Xu ZJ, Zheng RS, Zhang SW, Zou XN and Chen WQ Nasopharyngeal carcinoma incidence and mortality in China in 2009. Chin J Cancer 32: 453-460, 2013.

2. Zhou W, Feng X, Ren C, Jiang X, Liu W, Huang W, Liu Z, Li Z, Zeng L, Wang L, et al: Over-expression of BCAT1, a c-Myc target gene, induces cell proliferation, migration and invasion in nasopharyngeal carcinoma. Mol Cancer 12: 53, 2013.

3. Burkitt MD, Williams JM, Duckworth CA, O'Hara A, Hanedi A, Varro A, Caamaño JH and Pritchard DM: Signaling mediated by the NF- $\kappa B$ sub-units NF- $\kappa B 1, N F-\kappa B 2$ and c-Rel differentially regulate Helicobacter felis-induced gastric carcinogenesis in C57BL/6 mice. Oncogene 32: 5563-5573, 2013.

4. Chung GT, Lou WP, Chow C, To KF, Choy KW, Leung AW, Tong CY, Yuen JW, Ko CW, Yip TT, et al: Constitutive activation of distinct NF- $\mathrm{BB}$ signals in EBV-associated nasopharyngeal carcinoma. J Pathol 231: 311-322, 2013.

5. Hamoudi RA, Appert A, Ye H, Ruskone-Fourmestraux A, Streubel B, Chott A, Raderer M, Gong L, Wlodarska I, DeWolf-Peeters C, et al: Differential expression of NF-kappaB target genes in MALT lymphoma with and without chromosome translocation: Insights into molecular mechanism. Leukemia 24: 1487-1497, 2010.

6. Colangelo T, Fucci A, Votino C, Sabatino L, Pancione M, Laudanna C, Binaschi M, Bigioni M, Maggi CA, Parente D, Forte N, et al: MicroRNA-130b promotes tumor development and is associated with poor prognosis in colorectal cancer. Neoplasia 15: 1086-1099, 2013.

7. Fitzgerald TL, Lertpiriyapong K, Cocco L, Martelli AM, Libra M, Candido S, Montalto G, Cervello M, Steelman L, Abrams SL and McCubrey JA: Roles of EGFR and KRAS and their downstream signaling pathways in pancreatic cancer and pancreatic cancer stem cells. Adv Biol Regul 59: 65-81, 2015

8. Dang K and Myers KA: The role of hypoxia-induced miR-210 in cancer progression. Int J Mol Sci 16: 6353-6372, 2015.

9. Taganov KD, Boldin MP, Chang KJ and Baltimore D: NF-kappaB-dependent induction of microRNA miR-146, an inhibitor targeted to signaling proteins of innate immune responses. Proc Natl Acad Sci USA 103: 12481-12486, 2006.

10. Dai L, Gu L and Di W: MiR-199a attenuates endometrial stromal cell invasiveness through suppression of the IKK $\beta / N F-\kappa B$ pathway and reduced interleukin-8 expression. Mol Hum Reprod 18: 136-145, 2012.

11. Zhen Q, Liu J, Gao L, Liu J, Wang R, Chu W, Zhang Y, Tan G, Zhao X and Lv B.: MicroRNA-200a Targets EGFR and c-Met to Inhibit Migration, Invasion, and Gefitinib Resistance in Non-Small Cell Lung Cancer. Cytogenet Genome Res. 146: 1-8, 2015.

12. Tsouko E, Wang J, Frigo DE, Aydodu E and Williams C. miR-200a inhibits migration of triple-negative breast cancer cells through direct repression of the EPHA2 oncogene. Carcinogenesis 36 : 1051-1060, 2015
13. Hong MH, Mai HQ, Min HQ, Ma J, Zhang EP and Cui NJ: A comparison of the Chinese 1992 and fifth-edition International Union Against Cancer staging systems for staging nasopharyngeal carcinoma. Cancer 89: 242-247, 2000.

14. Guo J, Li M, Meng X, Sui J, Dou L, Tang W, Huang X, Man Y, Wang S and Li J: MiR-291b-3p induces apoptosis in liver cell line NCTC1469 by reducing the level of RNA-binding protein HuR. Cell Physiol Biochem 33: 810-822, 2014.

15. Kan R, Shuen WH, Lung HL, Cheung AK, Dai W, Kwong DL, Ng WT, Lee AW, Yau CC, Ngan RK, Tung SY and Lung ML: NF- $\kappa$ B p65 Subunit Is Modulated by Latent Transforming Growth Factor- $\beta$ Binding Protein 2 (LTBP2) in Nasopharyngeal Carcinoma HONE1 and HK1 Cells. PLoS One 10: e0127239, 2015.

16. Astarci E, Sade A, Cimen I, Savaş B and Banerjee S: The NF-кB target genes ICAM-1 and VCAM-1 are differentially regulated during spontaneous differentiation of Caco-2 cells. FEBS J 279: 2966-2986, 2012.

17. Lu Z, Li Y, Takwi A, Li B, Zhang J, Conklin DJ, Young KH, Martin R and Li Y: miR-301a as an NF- $\kappa$ B activator in pancreatic cancer cells. EMBO J 30: 57-67, 2011

18. Bao C, Li Y, Huan L Zhang Y, Zhao F, Wang Q, Liang L, Ding J, Liu L, Chen T, Li J, Yao M, Huang S, He X.: NF- $\kappa$ B signaling relieves negative regulation by miR-194 in hepatocellular carcinoma by suppressing the transcription factor HNF-1 $\alpha$. Sci Signal 8: ra75, 2014.

19. Ding J, Huang S, Wang Y, Tian Q, Zha R, Shi H, Wang Q, Ge C, Chen T, Zhao Y, Liang L, Li J and He XP: Genome-wide screening reveals that miR-195 targets the TNF- $\alpha / N F-\kappa B$ pathway by down-regulating IкB kinase alpha and TAB3 in hepatocellular carcinoma. Hepatology 58: 654-666, 2013.

20. Olarerin-George AO, Anton L, Hwang YC, Elovitz MA and Hogenesch JB: A functional genomics screen for microRNA regulators of NF-kappaB signaling. BMC Biol 11: 19, 2013.

21. Croce CM: Causes and consequences of microRNA dysregulation in cancer. Nat Rev Genet 10: 704-714, 2009.

22. Liu N, Cui RX, Sun Y, Guo R, Mao YP, Tang LL, Jiang W, Liu X, Cheng YK, He QM, et al: A four-miRNA signature identified from genome-wide serum miRNA profiling predicts survival in patients with nasopharyngeal carcinoma. Int J Cancer 134: 1359-1368, 2014.

23. Zhao Y, Chen X, Jing M, Du H and Zeng Y: Expression of miRNA-146a in nasopharyngeal carcinoma is upregulated by Epstein-Barr virus latent membrane protein 1. Oncol Rep 28: 1237-1242, 2012

24. Song L, Liu L, Wu Z, Li Y, Ying Z, Lin C, Wu J, Hu B, Cheng $\mathrm{SY}, \mathrm{Li} \mathrm{M}$ and $\mathrm{Li}$ J: TGF- $\beta$ induces miR-182 to sustain NF- $\mathrm{KB}$ activation in glioma subsets. J Clin Invest 122: 3563-3578, 2012.

25. Pozdeyev N, Berlinberg A, Zhou Q, Wuensch K, Shibata H, Wood WM and Haugen BR: Targeting the NF- $\mathrm{BB}$ pathway as a combination therapy for advanced thyroid cancer. PLoS One 10: $\mathrm{e} 0134901,2015$.

26. Nourbakhsh M, Oumard A, Schwarzer M and Hauser H: NRF, a nuclear inhibitor of NF-kappaB proteins silencing interferon-beta promoter. Eur Cytokine Netw 11: 500-501, 2000. 